\title{
Analysing prosody and meaning in Spanish: implications for the teaching of English as a foreign language
}

\author{
Valeria Fernanda Arana \\ Master of Lingüística Aplicada a la Enseñanza \\ del Inglés como Lengua Extranjera. Facultad de \\ Lenguas, Universidad Nacional del Comahue, \\ Argentina. \\ valeriaarana@gmail.com
}

\section{Gonzalo Eduardo Espinosa}

Becariodoctoral. Facultad de Lenguas, Universidad Nacional del Comahue, Argentina.

gonzaedward@hotmail.com

\section{Abstract: The aim of this work is to identify the} difficulties that Spanish learners of English may have when confronted with the L2 intonation. The different tone choices made by native speakers of Spanish in North Patagonia, Argentina, are analysed in the light of the Autosegmental-Metrical framework (LADD, 1996) and the Relevance Theory (SPERBER and WILSON, 1995, 2004). The findings are compared with the tone choices produced by native speakers of English. The main results indicate that the same procedural instruction is manifested in both languages by means of $L^{*} L \%$ and $H+L^{*} L \%$. However, Spanish favours $L^{*}$ whereas English prefers $H+L^{*}$.

Keywords: tone choices; pragmatics; L1

\section{Bettiana Andrea Blázquez}

Master of Arts in English Language Teaching and Applied Linguistics. Facultad de Lenguas, Universidad Nacional del Comahue, Argentina. bettianablazquez@hotmail.com

\section{Lucía Soledad Valls}

Licenciada em de Língua Inglesa. Facultad de Lenguas, Universidad Nacional del Comahue, Argentina.

luciasvalls@hotmail.com

Resumo: O objetivo deste trabalho é identificar as possíveis dificuldades que os alunos falantes de Espanhol podem ter quando se confrontarem com o sistema de entonação Inglês. As diferentes escolhas de tom feitas por falantes nativos de Espanhol na região da Patagonia Norte, Argentina, são analisadas com as teorias do quadro autossegmental-métrico (LADD, 1996) e da relevância (SPERBER and WILSON, 1995, 2004), e comparadas com as escolhas de tom feitas por falantes nativos de Inglês. Os principais resultados encontrados foram que nas duas línguas a instrução processual é $L^{*} L \%$ e $H+L^{*} L \%$. As diferenças são: Espanhol: $L^{*}$, e Inglês: $H+L^{*}$.

Palavras-chave: escolhas de tom; pragmática; L1 



\section{Introduction}

This work emerges from a research project on prosody and relevance in English and Spanish that is being carried out at Facultad de Lenguas, Universidad Nacional del Comahue in Argentina.

The overall aim of this research paper is to identify the potential difficulties that Spanish learners of English may have when being confronted with the English intonation system. The tone choices ${ }^{1}$ made by native speakers of Spanish at Comahue region, North Patagonia, Argentina, will be examined with the purpose of paving the way for the improvement in teaching and learning intonation. The present study intends to analyse the prosody of declaratives from a pragmatic and a phonological point of view. A theoretical background will be outlined, particularly SPERBER and WILSON's Relevance Theory (SPERBER and WILSON, 1995, 2004), and its application to the study of prosody (HOUSE, 1990; WILSON and WHARTON, 2006). The gathered data will be analysed in the light of the AutosegmentalMetrical framework (LADD, 1996) and the findings on Spanish as an L1 will be compared with the tone choices made by native speakers of English from the South East of England.

\section{Theoretical Framework}

\section{Relevance Theory}

Pragmatic theory is concerned with the interpretation of the speaker's meaning expressed through utterances. In Gricean pragmatics (cf. GRICE, 1991), it is considered an inferential process of hypothesis formation and evaluation. The possible hypotheses are evaluated in the light of certain general principles of communication which speakers are expected to obey.

\author{
${ }^{1}$ Within Relevance \\ Theory the term choice \\ is understood as an \\ element of procedural \\ encoding. A speaker \\ 'chooses' certain \\ intonational contours \\ unconsciously to cause \\ an effect on the listener \\ and guide him/her in \\ the interpretation of \\ utterances.
}


Relevance Theory, a neo-Gricean cognitive pragmatic theory, proposes that our cognitive life and consequently our linguistic utterances are guided by the search for relevance. This means that the interpretation of utterances is governed by two general principles: a communicative and a cognitive one.

Communication, according to this theory, combines the traditional process of codification with processes of inference. This combination suggests the existence of a speaker that wants his utterances to be understood, and a listener that provides a context for the interpretation of those utterances. The so called ostensive-inferential process holds that the listener infers the speaker's intention in order to process the information in an efficient way. This is achieved if the speaker directs the listener's attention to what the former considers relevant.

The general cognitive principle states that we pay attention to what is relevant. Hearers are equipped with a very general cognitive criterion to evaluate interpretations, which is based on the fundamental assumption mentioned above. Every utterance has a variety of possible interpretations, but not all of them occur to the hearer simultaneously: some demand more effort to work out. Therefore, relevance is defined in terms of contextual effects and processing effort. Contextual effects are achieved when newly-presented information interacts with a context of existing assumptions in one of three ways: by strengthening existing assumptions; by contradicting and eliminating existing assumptions; or by combining with existing assumptions to yield a contextual implication, a synthesis of old and new information.

An utterance which provides great cognitive effects requires little effort on the part of the listener. The relevance results from the interaction between the new information that the utterance conveys and the one 
that is known or derived from the context: the lower the effort to process the message, the greater the relevance. On the contrary, an utterance that requires greater effort to be interpreted produces fewer cognitive effects, thus, the less relevant it will seem.

\section{Autosegmental-Metrical Model}

The autosegmental-metrical model (AM) is based on PIERREHUMBERT's (1980) doctoral thesis. It was originally meant to describe the English language; however, it has been revised and employed in other languages, including Spanish.

In the AM model, intonation is conceived of as an independent level from the segments, and contours are broken down into contrastive components. It basically distinguishes two types of prosodic domains: the intonational phrase and the intermediate phrase. There are two phonological units: pitch accents, which are anchored with prominent syllables, and boundary tones, which are associated with the edges of prosodic domains. This approach proposes two tone levels: $\mathrm{H}$ (High) and L (Low), which are linked to pitch accents and edge tones. The $\left(^{*}\right)$ symbol indicates the association of the prosodic event with the prominent syllable. The $(-)$ symbol corresponds to the intermediate phrase, and the (\%) relates the tone to the edge of the intonational phrase. A third level, M (Mid), for the boundary tone has been described in the analysis for the Spanish language.

Based on the AM model prosody has been analysed by means of the Tone and Break Indices (ToBI) transcription system (BECKMAN, 2002). This notational tool examines strings of phonological events and consists of different tiers to annotate tones, words, syllables, break indexes and any other extra linguistic aspect. ToBI has been implemented for the study of several languages, 
including Spanish (Sp-ToBI) (BECKMAN ET AL., 2002; HUALDE, 2003; SOSA, 2003; ESTEBAS VILAPLANA and PRIETO, 2008). The Sp-ToBI transcription system has resulted from agreement reached by specialists working in the autosegmental-metrical framework (BECKMAN and ELAM, 1997). The latest modifications to Sp-ToBI have been introduced by ESTEBAS and PRIETO (2008) and the Sp-ToBI conventions for Argentinian Spanish have been put forward by GABRIEL et al. (2010).

\section{Methodology}

\section{Corpus}

The data collection was organised in two stages. In the first place, a narrative piece was chosen to be read aloud by the participants as this genre is characterised by containing mainly declaratives. The short story selected was “A Imagen y Semejanza” by BENEDETTI (1968). This text was shortened as a fragment of the tale would provide a sufficient sample of the language for its later analysis. Then, the resulting version was translated into English. Attention was placed on declaratives which coincided with full stops in the short story. There is a clear correlate between punctuation and intonation (CRUTTENDEN, 1997). One of the functions of punctuation is to delimit the beginning and end of a tone unit, not necessarily by means of a pause. Accordingly, the readers in this work segmented their speech in a similar fashion due to the influence of punctuation. However, this division of oral language does not imply the same choice of tones. This is why instances of similar segmentation but different tone choices were encountered.

The second stage consisted of gathering the Spanish and English data. As regards Spanish, the subjects of study were two male and two female university 
students aged 21 who had just started the teacher training and translation courses with some basic previous knowledge of English. All of them were native speakers of the variety of Spanish spoken in the Comahue region, North Patagonia; they were all born and raised in this area and their parents had lived there for at least 20 years. As to the English data, the subjects of study were four male native speakers from the South East of England in their late 20s. All the participants were asked to read the fragment out loud obtaining one recording per subject. Once the interviews were carried out, the linguistic data were transcribed.

\section{Analysis and transcription tools}

One of the tools used for analysing speech and transcribing data was the computer programme Praat 5.2.25 (BOERSMA and WEENINK, 2010). This software shows the waveform together with the F0 in parallel and coordinated windows and allows researchers to follow the conventions for ToBI, i.e. the notation may be divided into different tiers such as words, tones, break indexes, syllables and the like. ToBI was not developed for interlinguistic analysis and this means that English ToBI and $\mathrm{Sp}$-ToBI are different. In order to be able to compare the preliminary observations obtained from both languages only one transcription system was necessary. In keeping with the aims of the research project, Sp-ToBI was favoured.

The other tool used for analysing speech was the auditory perception of the researchers. It is worth mentioning that the F0 not always reflects tone movements exactly. In the case of low-pitched voices and voiceless sounds, the F0 track is broken and, as a consequence, errors in the representation of it may occur. This is why the perceptual analysis of the researchers 
is combined with computational tools to optimise the analysis of the data.

\section{Data Analysis}

\section{Phonetic and phonological analysis}

During the process of analysis, the first step consisted of exploring the readings by means of auditory perception. Each of the recordings was divided into intonational phrases and then prominent syllables and nuclear accents were located. One aspect taken into consideration when selecting the intonational phrases to be analysed was the location of the nuclear accent. In order to make a clear and separate analysis of the nuclear pitch accents and boundary tones the focus was placed on intonational phrases that did not bear the nuclear accent on the last syllable. The next step comprised the segmentation of the audio files so as to proceed with the acoustic analysis. The preliminary auditory testing was checked by means of the software Praat: nuclear accents and boundary tones were identified. Then, the performance of the four Spanish participants was contrasted with one another. The same procedure was followed for the English subjects. Finally, the information about both languages was compared.

\section{Nuclear accents}

The nuclear tones used by the Spanish subjects were of three types: $\mathrm{L}^{*}, \mathrm{H}+\mathrm{L}^{*}$ and $\mathrm{L}+\mathrm{H}^{*}+\mathrm{L}$. In the case of English, two nuclear tone types were identified: $\mathrm{L}^{*}$ and $\mathrm{H}+\mathrm{L}^{*}$. A schematic representation, together with a brief description of each pitch accent, is shown in table 1 below. 


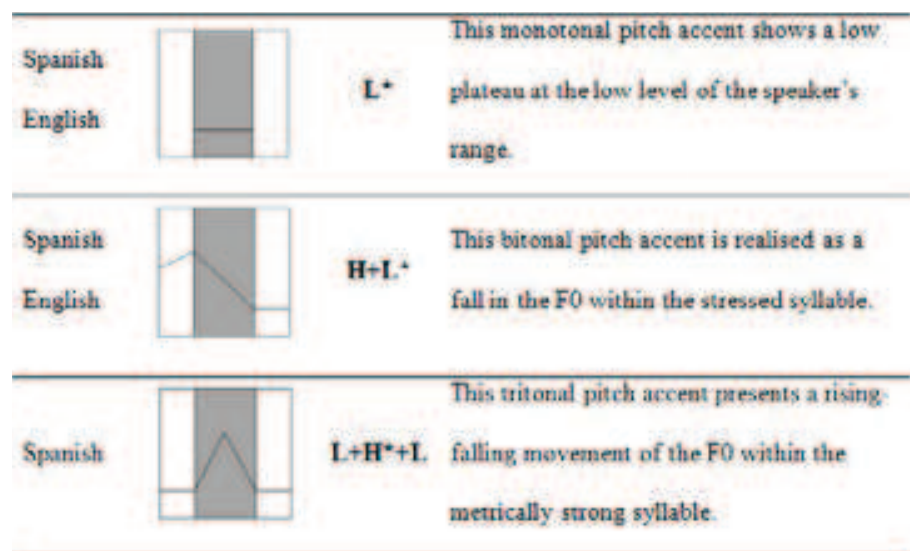

Table 1: Inventory of nuclear tones found in declarative sentences in the studied varieties of Spanish and English.

The most frequent nuclear tone choice made by the Spanish speakers was L*, standing for a 59 per cent of the corpus, followed by $\mathrm{H}+\mathrm{L}^{*}$ as a second choice with a 35 per cent of occurrence. In opposition, the English subjects preferred $\mathrm{H}+\mathrm{L}^{*}$ as the nuclear pitch accent in a noticeable 71 per cent, leaving a low 29 per cent for $\mathrm{L}^{*}$. The tritonal nuclear accent $\mathrm{L}+\mathrm{H}^{*}+\mathrm{L}$ was only found in the Spanish data in a six per cent. This nuclear tone is typically used in Argentinian Spanish intonation in utterances with a contrastive or emphatic reading (GABRIEL ET AL., 2010). The following pie charts show the frequency of occurrence of each nuclear tone in both languages.

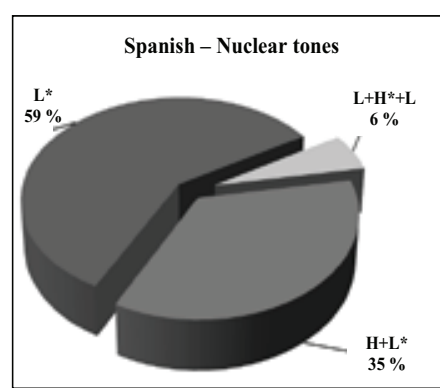

Fig. 1: Spanish nuclear tones

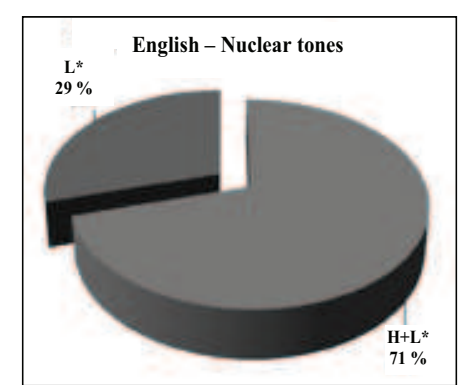

Fig. 2: English nuclear tones 


\section{Boundary tones}

Concerning boundary tones, the analysis revealed that both languages make use of L\%. The Spanish corpus also presented the occurrence of $\mathrm{M} \%$. Table 2 below summarises these edge tones.

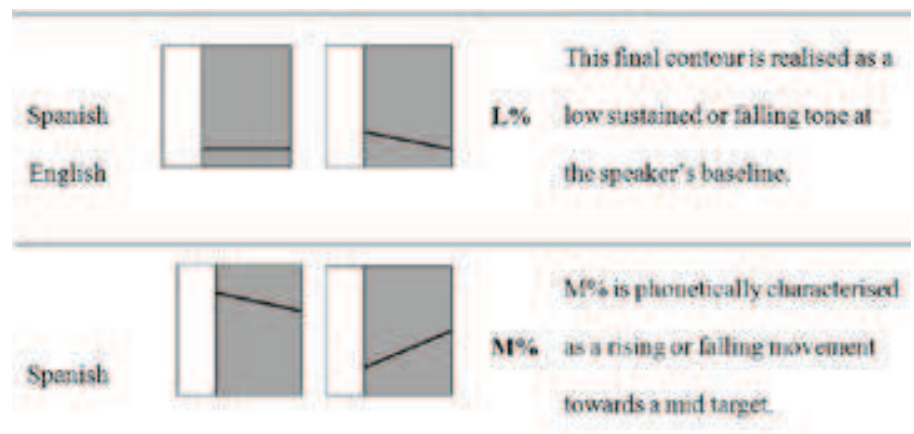

Table 2: Inventory of boundary tones found in declarative sentences in the studied varieties of Spanish and English.

In both languages the tendency was to use the low level tone target: L\%. In Spanish, this edge tone was found in 82 per cent of all instances, whereas in English, L\% appeared in 100 per cent of the analysed declaratives. The M\% was only identified in the Spanish data, representing an 18 per cent of the corpus. Figures 3 and 4 show the frequency of occurrence of each boundary tone in both languages.

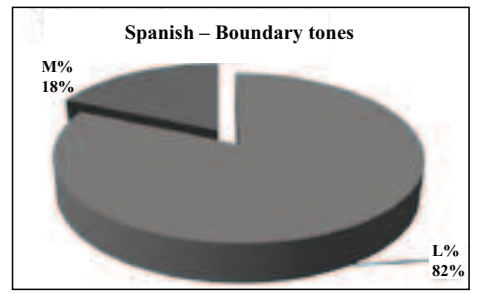

Fig. 3: Spanish boundary tones

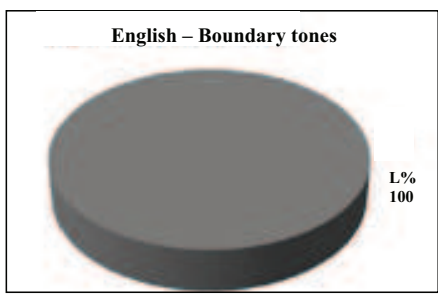

Fig. 4: English boundary tones

The high boundary tone $\mathrm{H} \%$ was not found in the collected data. This type of edge tone might be associated 
with questions, a sentence type which was not analysed in this study and should be part of further research.

\section{Nuclear configurations}

In relation to tonal configurations, the Spanish subjects used the following combinations: $\mathrm{L}^{*} \mathrm{~L} \%, \mathrm{H}+\mathrm{L}^{*} \mathrm{~L} \%$, $\mathrm{L}^{*} \mathrm{M} \%, \mathrm{H}+\mathrm{L}^{*} \mathrm{M} \%$ and $\mathrm{L}+\mathrm{H}^{*}+\mathrm{L} \mathrm{L} \%$. In the case of English, only two nuclear configurations were identified: $\mathrm{H}+\mathrm{L}^{*} \mathrm{~L} \%$ and $\mathrm{L}^{*} \mathrm{~L} \%$. Table 3 shows these combinations.

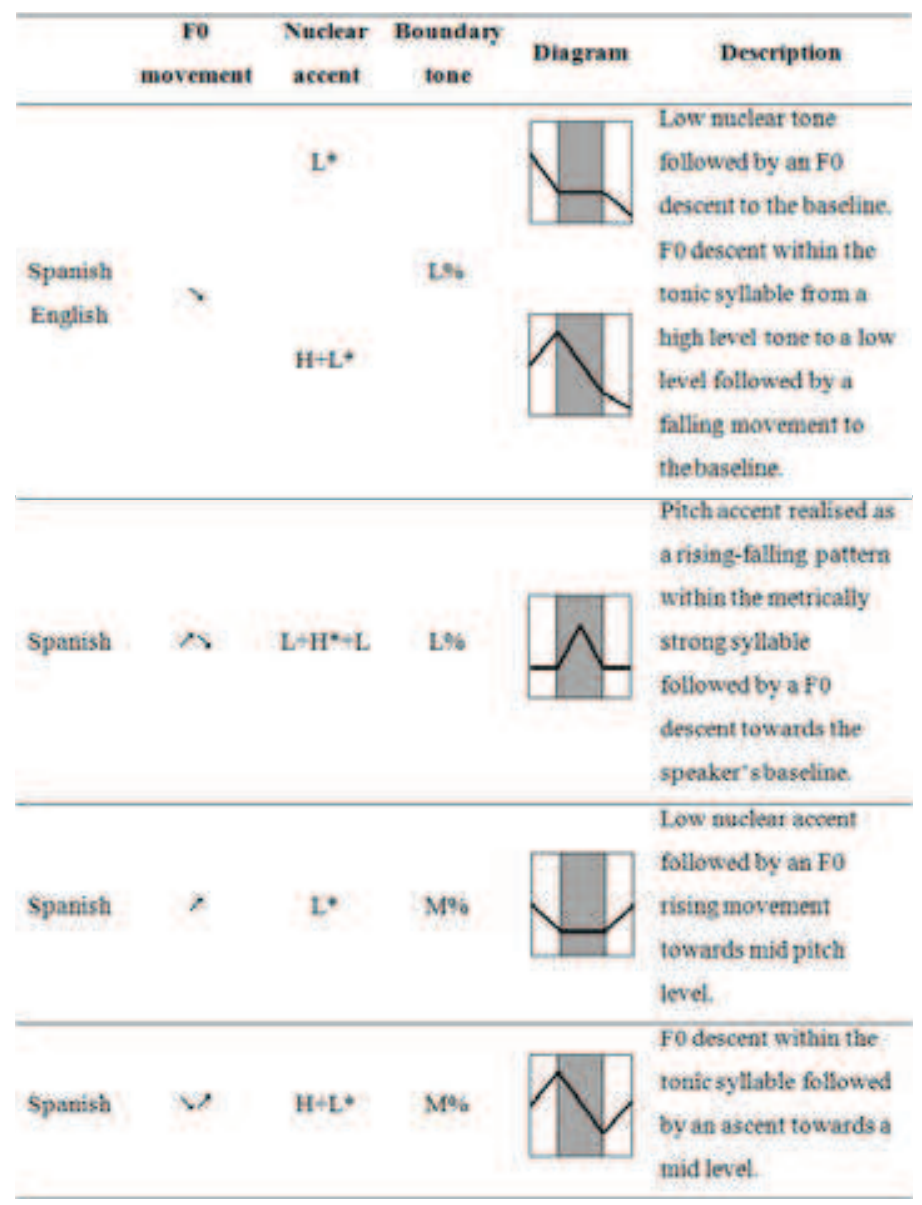

Table 3: Inventory of tonal configurations identified in Spanish and English. 
With regard to the percentages of nuclear configurations, 47 per cent of the declaratives in Spanish were produced with a low accent $L^{*}$ followed by a low boundary tone, L\%. This percentage can be directly compared with the one obtained in the English data, as only 29 per cent of all the cases were uttered with this nuclear configuration. Likewise, most declaratives, 71 per cent, were produced with a $\mathrm{H}+\mathrm{L}^{*}$ nuclear pitch accent and a L\% phrase boundary. This configuration displays a falling movement of the F0 track down to the pitch baseline $(\searrow)$ and it appeared in the Spanish data as well, but in a lower percentage, 26 per cent. The Spanish corpus also revealed that 12 percent of the prosodic units combined $\mathrm{L}^{*}$ with a mid boundary tone, $\mathrm{M} \%$, and 9 per cent of the cases showed a $\mathrm{H}+\mathrm{L}^{*}$ pitch accent followed by a mid edge tone, $\mathrm{M} \%$. This configuration displays an ascent of the F0 in the post tonic material up to a mid level point $(\nearrow)$. According to the data, the tritonal tone $\mathrm{L}+\mathrm{H}^{*}+\mathrm{L}$ followed by a low boundary tone, $\mathrm{L} \%$, was the least used by the Spanish speakers as just 6 per cent of the declaratives were produced with this configuration. Figures 5 and 6 represent all the tonal configurations detailed above:
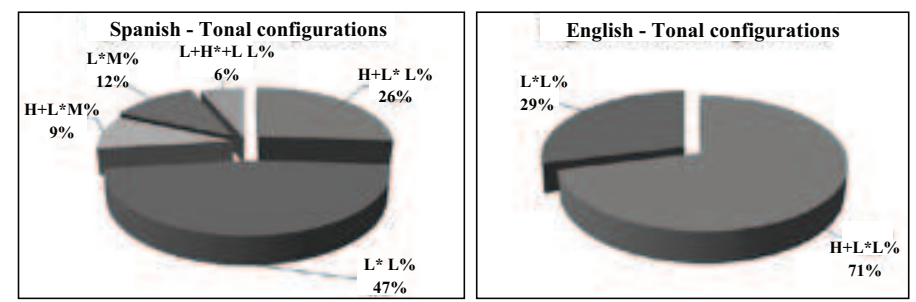

Fig. 5: Spanish tonal configurations Fig. 6: English tonal configurations

Overall, the corpus suggests that the most typical tonal configuration used by the Spanish subjects was $L^{*}$ $\mathrm{L} \%$, while native speakers of English produced $\mathrm{H}+\mathrm{L}^{*} \mathrm{~L} \%$ in most of the cases. These nuclear configurations may be observed in figures 7 and 8 below: 


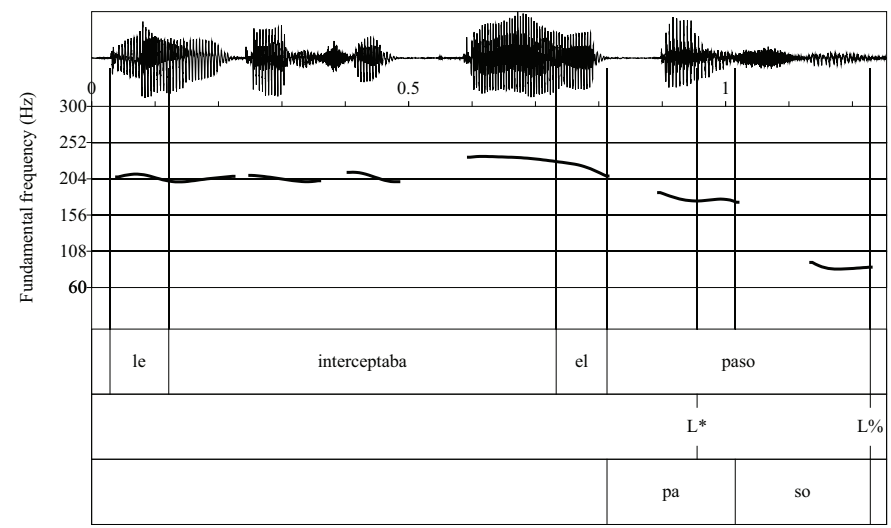

Fig. 7: Waveform, spectrogram and F0 trace for the declarative $L e$ interceptaba el paso produced with a $\mathrm{L}^{*} \mathrm{~L} \%$ tonal configuration.

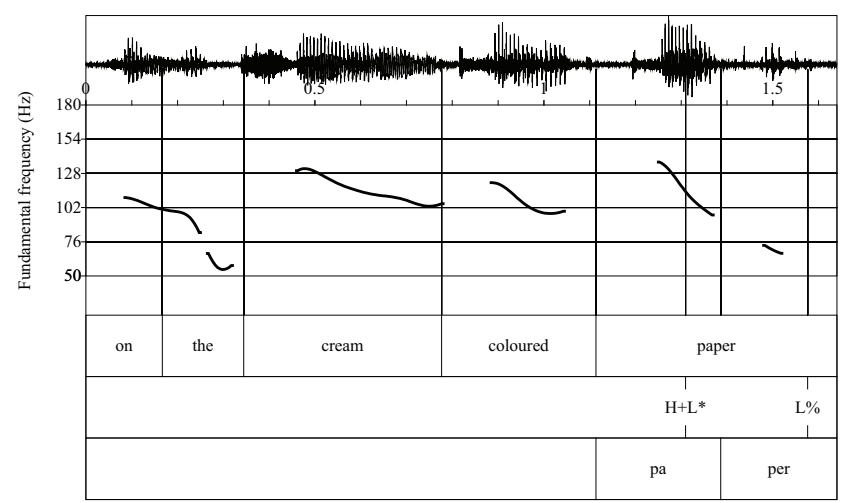

Fig. 8: Waveform, spectrogram and F0 trace for the declarative on the cream coloured paper produced with a $\mathrm{H}+\mathrm{L} * \mathrm{~L} \%$ nuclear configuration.

Only a few of the examples from the Spanish data (21\%) showed a rising movement from a low nuclear pitch accent $\mathrm{L}^{*}$ or $\mathrm{H}+\mathrm{L}^{*}$ towards a mid target $\mathrm{M} \%$. This rising configuration is typically used in uncertainty statements (GABRIEL ET AL., 2010). 


\section{Pragmatic analysis}

Intonation works as a procedural indicator of the relative relevance in utterances. By means of different voice inflections, the speaker guides the listener towards the intended message, so that the hearer makes as little effort as possible when processing oral input. A previous study on Spanish spoken in the Comahue region, North Patagonia, (ARANA ET AL., 2010) showed that intonation, and most specifically boundary tones, encodes specific instructions as to how each utterance should be interpreted:

1) Suspended tonal configurations $(\rightarrow)$ such as $\mathrm{H}+\mathrm{L}^{*}$ $\mathrm{M} \%, \mathrm{~L}+\mathrm{H}^{*} \mathrm{M} \%$ or $\mathrm{L}^{*} \mathrm{M} \%$, indicate continuity: they tell the hearer that this intonational unit is part of a bigger structure. In spite of being complete, grammatically and semantically speaking, the tonal configuration shows incompleteness or non-finality, and thus the hearer learns that the relevance of the utterance is to be found in what follows.

2) Falling tonal configurations $\left(\searrow\right.$ ) of the type $L^{*} L \%$ and $\mathrm{H}+\mathrm{L}^{*} \mathrm{~L} \%$ signal finality: they specify that the sense of incompletion achieved by means of the previous utterances is about to end. The relevance of this utterance depends on what is achieved by the phrase itself; it is part of the directly relevant information.

These findings were the starting point of this work and the scope of analysis was broadened by also examining English data. Attention was directed towards falling contours in declaratives at the end of intonational phrases in both languages, so as to observe possible differences between Spanish and English. 
Examples (1) and (2) illustrate the preferred tonal sequences in both languages and their pragmatic meaning in terms of procedural instructions in Relevance Theory:

(1) S7_L_O_3

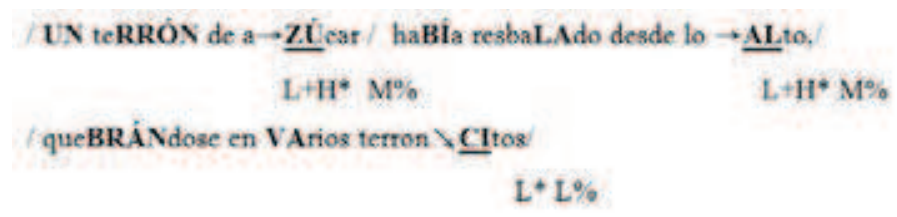

In the Spanish example, the first two utterances "un terrón de azúcar" and "había resbalado desde lo alto" show the tonal configuration $\mathrm{L}+\mathrm{H}^{*} \mathrm{M} \%(\rightarrow)$. These suspended contours show non-finality and indicate the interpretation process should be postponed. The last tone unit "quebrándose en varios terroncitos" has the falling tonal configuration $\mathrm{L}^{*} \mathrm{~L} \%(\searrow)$, which indicates finality. The hearer has now been instructed to process the whole group of tone units.

The 21\% of cases of declaratives at the end of intonational phrases with a rising nuclear configuration, found in the Spanish data, $\mathrm{L}^{*} \mathrm{M} \%$ or $\mathrm{H}+\mathrm{L}^{*} \mathrm{M} \%$, could be interpreted as uncertainty statements (GABRIEL ET AL., 2010). However, they will be not examined pragmatically in this work because they deserve a detailed analysis in a further study.

(2) K_O_1

$$
\begin{aligned}
& \text { he was the LAST ANT in the } \searrow>\text { CAravan / } \\
& \mathrm{H}+\mathrm{L} * \quad \mathrm{M} \% \\
& \text { / and he COULDn't keep UP with his } \backslash \underline{\text { MATES }} \\
& \mathrm{H}+\mathrm{L} * \mathrm{~L} \%
\end{aligned}
$$

These tone units make up the first sentence in the English version of the story. Thefirst one "he was thelastant in the caravan" shows the suspended tonal configuration $\mathrm{H}+\mathrm{L}^{*} \mathrm{M} \%(\searrow>)$, which indicates incompleteness and 
makes up the context for processing information, as in the Spanish data. Accordingly, it invites the hearer to postpone evaluating the relevance of the utterance until a falling contour follows. The last intonational phrase "and couldn't keep up with his mates" shows the falling tonal configuration $\mathrm{H}+\mathrm{L}^{*} \mathrm{~L} \%(\searrow)$. By means of this contour, the speaker indicates that the information of the present tone unit and the previous one should be processed. A falling contour shows conclusiveness: the speaker has offered the directly relevant information.

It can be observed that the boundary tone is the same as the one in the Spanish example above, but the nuclear accent is different: $\mathrm{H}+\mathrm{L}^{*}$. It seems that the procedural instruction encoded in the falling contour is the same in both languages, irrespective of the nuclear tone choice. The procedural instructions for both languages could be summarised as follows: a) in the presence of a suspended contour $(\rightarrow \searrow \nearrow)$, the listener should postpone the evaluation of the global relevance of this utterance until a L\% tone is reached; $b$ ) when there is a falling contour $(\searrow)$ the listener should evaluate the global relevance of the previous tone unit(s) in the light of the content of the this particular intonational phrase. Through the tone choices the speaker makes, the hearer is helped to find the most relevant interpretation of the utterances.

The data analysed in the light of Relevance Theory give evidence of procedural encoding. The tone units that show a suspended tonal configuration create great cognitive effects. This optimises the interpreting process and when the listener reaches the tone unit with a falling contour, little effort is necessary: the lower the effort to process the message, the greater the relevance. This interpretation procedure would require some extra effort on the part of the listener if each tone unit was processed separately. 


\section{Discussion}

Having analysed and contrasted both languages, differences have been found as to the preferred nuclear tone choices, but not as to the selection of the boundary tone. It can be clearly observed that while Spanish prefers $L^{*} \mathrm{~L} \%$ when reaching a full stop, English, on the other hand, chooses $\mathrm{H}+\mathrm{L}^{*} \mathrm{~L} \%$, in the examined corpus. This difference does not seem to have any pragmatic implications, although further study is necessary.

The difference in the choice of nuclear tones might be related to a phonetic phenomenon. The abrupt fall in the F0 produced by the bitonal $\mathrm{H}+\mathrm{L}^{*}$ pitch accent followed by L\% is preferred by English speakers over the less notorious fall manifested in a $L^{*}$ $\mathrm{L} \%$ combination in Spanish. It could be argued that the analysed Spanish speakers did not produce an abrupt fall of the F0 given that Spanish in North Patagonia seems to display a narrower pitch range, which coincides with the descriptions of other varieties of Spanish. This pitch range difference might be associated with the rhythmical structure of each language. Even though, more empirical evidence is needed.

The above-mentioned remarks pave the way for predicting our students' difficulties in learning the English intonation system. The phonetic characterisations of both languages might suggest that these students need to broaden their pitch range when performing English tunes.

A future step in the analysis would consist of asking the students to read the tale in English and see if Spanish intonation influences the target language. If so, it would be interesting to examine which aspects of intonation are the ones which learners apply when reading English so as to design a course of action to help solve these problems. 


\section{Conclusion}

Intonation plays a crucial role when speakers instruct the hearers how to process the information. Relevance Theory seems to give a suitable framework for accounting for the meaning of different voice inflections. The falling nuclear configuration instructs the hearer to process the information presented as directly relevant.

In this work, the pragmatic information conveyed in Spanish and English was substantially the same, i.e. the hearer was instructed to process the utterances as foreground information at the moment the pitch movement was occurring. However, the differences lied on the phonetic and phonological manifestation of the analysed data. Spanish speakers told the hearer to process their message by means of $\mathrm{L}^{*} \mathrm{~L} \%, \mathrm{H}+\mathrm{L}^{*} \mathrm{~L} \%$, and $\mathrm{L}+\mathrm{H}^{*}+\mathrm{L}$ L\%, whereas English speakers preferred $\mathrm{H}+\mathrm{L}^{*} \mathrm{~L} \%$ and $\mathrm{L}^{*}$ $\mathrm{L} \%$ in order to give the same procedural instruction.

This study on pragmatic values and phonology has thrown new light on cross-linguistic similarities and differences. These preliminary findings provide us with an insight into what should be done in order to help our students learn the English intonation system. 


\section{References}

ARANA, V. et al. Selección tonal en el español y el inglés habado: bases para una propuesta pedagógica, en actas $1^{\text {er }}$ Congreso Nacional El conocimiento como espacio de encuentro. ISBN 978-987-604-208-6, 2010.

BECKMAN, M. et al. Intonation across Spanish, in the Tones and Break Indices framework. Probus 14, 2002. p.9-36.

BENEDETTI, M. A imagen y semejanza. IN: BENEDETTI, M. La muerte y otras sorpresas. Madrid: Alfaguara, 1968.

BOERSMA, P. and WEENINK, D. Praat: Doing phonetics by computer. Version 5.1.25. Available at: <www.praat.org $>$. Retrieved: 5 August, 2010.

CRUTTENDEN, A. Intonation. $2^{\text {nd }}$ edition. New York: Cambridge University Press, 1997.

ESTEBAS-VILAPLANA, E. and PRIETO, P. La notación prosódica en español: Una revision del Sp_ToBI. Estudios de Fonética Experimental XVII, 2008. p. 263-283.

GABRIEL, C. et al. Argentinian Spanish intonation. IN: Prieto, P. and Roseano, P. (eds.) Transcription of Intonation of the Spanish Language. München: Lincom Europa, 2010.

GRICE, H. P. Studies in the Way of Words. USA :Harvard University Press. 1991.

HOUSE, J. Intonation structures and pragmatic interpretation. IN: Ramsaran, S. (ed.) Studies in the Pronunciation of English. London: Routledge, 1990. p. 38-57.

HUALDE, J.I. El modelo métrico-autosegmental. IN: Prieto, P. (ed.) Teorías de la Entonación. Barcelona: Ariel, 2003. p. 155-184.

LADD, D.R. Intonational Phonology. Cambridge: Cambridge University Press, 2008. 
PIERREHUMBERT, J. The phonology and phonetics of English intonation, PhD dissertation. MIT. Massachusetts: Cambridge, 1980.

SOSA, J.M. La notación tonal del español en el modelo Sp_ ToBI. IN: Prieto, P. (ed.) Teorías de la Entonación. Barcelona: Ariel, 2003. p. 185-208.

SPERBER, D. and WILSON, D. Relevance: Communication and Cognition. Oxford: Blackwell, 1995.

WILSON, D. and SPERBER, D. Relevance Theory. IN: Horn, L. and Ward, G. (eds.) The Handbook of Pragmatics. Oxford: Blackwell, 2004. p. 607-632.

WILSON, D. and WHARTON, T. Relevance and Prosody. Journal of Pragmatics, Vol. 38, Issue 10, 2006. p. 1559-1579.

[Recebido em 30 de junho de 2013

e aceito para publicação em 29 de novembro de 2013] 